\title{
Morphology, Histology and Serotonin Distribution on Digestive Tract of Stick Insect, Phobaeticus serratipes (Phasmida: Phasmatidae)
}

\author{
${ }^{1}$ Wan Nurul 'Ain, W.M.N and ${ }^{1}$ Nurul Wahida Othman
}

\begin{abstract}
This study was conducted to identify the morphology of digestive tract of stick insect, Phobaeticus serratipes (Phasmida: Phasmatidae) as well as its histological structure. The distribution of biogenic amine, serotonin on the structure was also determined. Samplings for this study were conducted in highland areas in Langkawi Island, Kedah, Fraser Hill, Pahang and Mount of Ledang, Johor. The in-situ and ex-situ observation on gross morphology of digestive tract was done using stereo microscope Stemi v10 that was connected with DSLR Canon EOS 6D camera. The histological study of the alimentary tract involves special staining procedures of Periodic Acid Schiff's reagent and Alcian blue method. Serotonin distribution was conducted using immunohistochemical method with Dylight as secondary antibody. The serotonin distribution was observed under fluorescence microscope Zeiss Axiocam MRm Apotome.2 with ZenPro 2012 software and also Olympus FSX100 microscope. Digestive tract morphology and histology showed that $P$. serratipes foregut is the longest section consists of the oral cavity, pharynx, esophagus, crop and proventriculus. Gastric caeca and ventriculus embodied the midgut area. Midgut having columnar epithelial cells as the major cells that serve its purposes in nutrient absorptions and enzymatic metabolisms. The hindgut was the shortest part of the digestive tract that consists of Malpighian tubules, ileum, colon, rectum and anus. The serotonin of digestive tract were scattered and disorganized and mostly found on the muscle cells.
\end{abstract}

Keywords--Histology, stick insects, Phobaeticus serratipes, digestive tract, serotonin

\section{INTRODUCTION}

$\mathrm{T}$ $\mathrm{HE}$ organs and digestion in insects shows great variation due to the differences in food consumption. The ability of the insects to adapt with the particular food materials as their source of nutrition is important for their growth, metamorphosis, reproduction and maintenance of the population. It also requires a unique combination in terms of behavior, physiology and biochemical process [1].

Insect digestive tract is divided into three main regions, foregut (stomodeum), midgut (mesenteron) and hindgut (proctodeum). Reference [2] page 770 states that foregut and hindgut were developed from ectoderm whereas midgut was from endoderm [3].

The functions of each part of the digestive tract are different between species. However, foregut always associated with food storage and fragmentation. Midgut involves in secretion of digestive enzyme, digestion and absorption. Meanwhile, hindgut works in excretion and electrolyte balance [2] - [3] - [4]. Phasmatodea are herbivorous chewing insects that feed on one or more species of plants [5] that also known as polyphagus.

${ }^{1}$ Universiti Kebangsaan Malaysia, Faculty of Science and Technology, School of Environmental and Natural Resource Sciences, Centre for Insects Systematics, 43600 Bangi, Selangor, Malaysia
Serotonin (5-hydroxytryptamine or 5-HT) is a monoamine neurotransmitter. Serotonin controls various physiological events in insects. For instance, on Drosophila melanogaster, the increasing level of serotonin will increase the duration of sleep of that species [6]. Besides that, serotonin also can increase or decrease the appetite of some insects. For example, the act of serotonin on nerve modulator of $D$. melanogaster will make this species reduce their food intake [7].

However, not much study has been done on the digestive tract of Phasmatodea. The role of serotonin in this species is not known. Therefore, the purpose of this study was to describe the morphology, histology and the serotonin distribution on digestive tract of the adult $P$. serratipes.

\section{MATERIALS AND Methods}

\section{A. Samples Preparation}

Overall 30 samples were collected for this study. Ten samples from Kedah, 17 samples from Pahang and 3 samples from Johor. Only fresh samples were used in this study. Stick insects were dissected in order to expose the internal organs for the in-situ and ex-situ observation of the digestive tract.

\section{B. Gross Morphology observation}

Samples were weighed before dissected to make sure the size of all samples were on the same range. Juvenile will be discarded. Solutions of methylene blue were injected into the joint segment between the legs and abdomen and also between the head and thorax of the stick insects. Samples were left at room temperature for an hour for the absorption of the colour into the tissues. Dissections were done in phosphate-buffered saline (PBS) and images of salivary glands in-situ and ex-situ were captured using stereo microscope Stemi v10 that attached with DSLR Canon EOS $6 \mathrm{D}$ camera.

\section{Histological Study}

The digestive tracts were fixed in the Bouin's solution for 2-4 hours. Bouin's solution was removed by washing in $70 \%$ ethanol, and the glands were dehydrated through a series of ethanol $(50 \%, 90 \%, 100 \%)$ for an hour each. Tissue was left in sub-Xylene for an hour, infiltrated with wax $(3 \mathrm{x}$ at $58^{\circ} \mathrm{C}$ ) and embedded. Tissue was sectioned (3-5 $\left.\mu \mathrm{m}\right)$ using Leica RM2245 microtome. The slides containing tissues were stained using Alcian blue staining followed by periodic acid-Shiff's reagent (PAS). Images of the stained sections were observed under light microscope (Zeiss Axio Scope) with iSolutionLite software.

\section{Tissue Sections Immunohistochemical Analysis}

Slides of tissues sections were taken through a series of solutions (xylene and ethanol $(2 \times 100 \%, 95 \%, 70 \%)$. A 
groove grounded was made around the tissue sections with a diamond pen. The slides were rehydrated with wash buffer (PBS) for 10 minutes. The excess wash buffer was drained. Slides were partially dried after removal from PBS but tissue sections were not allowed to dry out. Next, 2 drops of pre-blocking agent PBT (PBS of $50 \mathrm{ml}+0.2 \%$ bovine serum albumin, $25 \mathrm{ul}+0.1 \%$ Triton $\mathrm{X}-100,5 \mathrm{ul}$ ) were used to cover tissue sections and left for 20 minutes and then tapped off and wiped away. Tissue sections were covered with diluted primary antibody (anti serotonin) (Abcam ab10385) or negative control (PBT). The primary antibody was diluted 1 in $1000(1 \mu \mathrm{l}$ in $1 \mathrm{ml}$ of PBT $+1 \%$ normal goat serum, 100ul $)$ $(\mathrm{PBT}+\mathrm{N})$. Slides were incubated at $4^{\circ} \mathrm{C}$ for overnight in a sealed incubation chamber and kept moist by lining the base with damp paper towel. Slides were then carried out from incubation chamber and repeated rinsing with PBS to wash off excess serum and drained. Tissues then covered with PBT plus normal goat serum $(\mathrm{PBT}+\mathrm{N})$. Some of the slides were incubated with different secondary antibody, that conjugated with Dylight (abcam ab96884) (dilution 1:300). Few drops of secondary antibody that conjugated with Dylight(1:300) were placed on the tissue at each slide and were incubated overnight $\left(4^{\circ} \mathrm{C}\right)$. The antibody was washed with PBT (30 min, 4x) before continuing wash it with PBS. The slides then taken into series of ethanol before mounted with Di-N-Butyle Phthalate Xylene (DPX) and covered with coverslip. The slides then dried out on a slide warmer for overnight. The slide was observed under fluorescence microscope (Zeiss Axiocam MRm Apotome.2) with ZenPro2012 software and Olympus FSX100 microscope.

\section{E. Whole Mount Tissue Immunofluorescense}

Fresh digestive tracts were fixed in $4 \%$ paraformaldehyde in PBS (18 hours at $\left.4^{\circ} \mathrm{C}\right)$. After washing with PBS, the tissue was permeabilized by incubate it to methanol (5 $\min \_70 \% \mathrm{MeOH}$ in PBS, 60min_100\% $\mathrm{MeOH}$ and $5 \mathrm{~min} \_70 \% \mathrm{MeOH}$ in PBS) before washing with PBS ( $5 \mathrm{~min}, 2 \mathrm{x}$ ). The tissues were incubated for $30 \mathrm{~min}$ in $100 \mathrm{~mL}$ of $\mathrm{PBT}+\mathrm{N}(\mathrm{PBT}+5 \%$ normal goat serum) before being processed with $100 \mathrm{~mL}$ of diluted (1: 1000) primary antibody serotonin (abcam ab10385) and incubated overnight at $4^{\circ} \mathrm{C}$. The antibodies were washed off by multiple rinses with PBS (5min, 3x) and PBT (45min, 2x). Then secondary antibody Dylight (abcam ab96884) $(1: 300)$ was added to each vial and the tissues were incubated at $4^{\circ} \mathrm{C}$ overnight. The tissues were washed in PBT $(5 \mathrm{~min}, 3 \mathrm{x})$ before a complete inversion in PBT for 2 hours. The tissues were cleared in mixture of $50 \%$ glycerol and $50 \%$ PBS overnight before mounting on slides. Controls were handled identically but the primary antibody was omitted during control tissue handling. The distribution of serotonin was observed under fluorescence microscope (Zeiss Axiocam MRm Apotome.2) with ZenPro2012 software and Olympus FSX100 microscope.

\section{RESUlt AND DiscusSiON}

\section{A. Gross Morphology of Digestive Tract}

Anatomy: The in-situ and ex-situ observation of gross morphology of the digestive tract Phobaeticus serratipes shows that foregut is located in prothorax, mesothorax and metathorax. Midgut was located between the first to fifth abdomen whereas hindgut from sixth abdomen to the anus.
The digestive tract is surrounded by muscles and tracheal system. The average length of digestive tract P.serratipes is $126.6 \mathrm{~mm} \pm 1.44$. Foregut is the longest part with the average length $55.96 \mathrm{~mm} \pm 1.61$. The average length for midgut is $38.1 \mathrm{~mm} \pm 1.50$ while hindgut is $32.4 \mathrm{~mm} \pm 1.78$ $\mathrm{mm}$.

Foregut: Foregut of P.serratipes consist of pharynx, esophagus, crop and proventriculus (Fig. 1). The pharynx and esophagus are long, straight and narrow. As they are the leaf eater, they require longer structure of foregut to help them to store the solids substances before further digestion by the enzyme in the midgut. The food is transferred into the digestive tract through the narrow opening that is called pharynx. This is where the peristalsis takes place and thus allowed the food to be channeled into the esophagus.

Esophagus of $P$. serratipes is a thin tube that elongated from thorax to the end of anterior abdomen. The food is then stored temporarily inside the crop.

The crop of this species have folded wall that can expand to maximize the capacity of food storage. The food that had been chewed into smaller size by mandible mouthpart with the help of the enzyme need to be grounded once again in the proventriculus. Ingested food does not usually undergo biochemical changes in the crop due to the absence of enzyme secretion in this area [8] - [4]. The nutrient absorption also is not fully occurred here because of the low permeability of the cuticles. There are some other insects that also have crop with very low permeability such as locust, Schistocerca gregaria, the cockroaches Gromphadorhina portentosa and Leucophaea mader, and in larvae of Lepidopteran, Manduca sexta [9]. This presumably explains earlier qualitative findings that the crop wall in several insect species has a low permeability [10] - [11] [12]. Such a low permeability will allows this part of the gut to be used as a temporary store for ingested material temporary store very different in its osmotic concentration from the hemolymph [9].

The proventriculus of P.serratipes is located at the posterior of foregut and have a very muscular and sclerotized teeth-like structure that plays an important role in grinding the food into smaller molecules and also to functioning as a valve that prevents backflow from midgut [13] - [14] - [15]. This part also have more networks of trachea and tracheal compared to other parts of the digestive tract.

Midgut: The midgut of P.serratipes is divided into gastric caeca and ventriculus (Fig. 1). This area is known to produce digestive enzyme, aid absorption of nutrients and also digestion [16]. The gastric caeca of P.serratipes are located at the anterior part of midgut while ventriculus situated at the posterios part. There are short finger-like projections on the stomodeal valve of the anterior part of gastric caeca.

There is no mucus gland or bolus recorded at the midgut of P.serratipes that cause the hard food molecules unable to be soften as in the vertebrate gut [17]. Reference [18] stated that there is a membrane that have similar function as the mucus gland that is called peritrophic membrane. This membrane is the mixture of protein and chitin [17]. This membrane is present in P.serratipes (Fig 2b).

Hindgut: Hindgut is the last part of the digestive tract that consist of Malpighian tubules, ileum, rectum and anus (Fig. 1). The Malpighian tubules of $P$. serratipes located between the ventriculus and ileum. Malpighian tubules are 
the long and fibrous hair-like structures that extend from the posterior part of the midgut. This structure marks the beginning of hindgut and play roles in the production of primary urine [16].

Hindgut also important in producing the insect faeces and, reabsorption of water and thus lead to the osmotic control in insects bodies [2].

As a solid feeder, the hindgut of $P$. serratipes is short because they does not need to reabsorb much water compared to liquid feeder insects. Part of hindgut that next to Malpighian tubules is known as ileum. Ileum is a long and thin gut that will expand to form a rectum at the posterior of hindgut while anus is an opening at the outside of posterior. The content in the hindgut usually in the liquid form when it is passed into the rectum. The rectum of $P$. serratipes is the biggest structure of the hindgut as it plays an important role in reabsorption of water, ions and dissolved materials including nutrients from primary urine that is passed from Malpighian tubules [16].

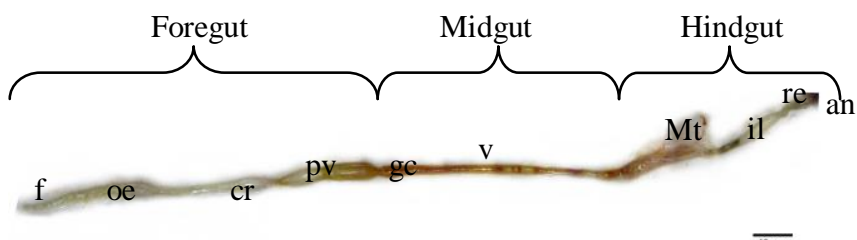

Fig. 1 Ex-situ digestive tract of P.serratipes. pharynx (f); esophagus (oe); crop (cr); proventriculus (pv); gastric caeca (gc); ventriculus (v); Malpighian tubules (Mt); ileum (il); rectum (re); anus (an)

\section{B. Histology of the Digestive Tract}

Foregut: The histological structure of $P$. serratipes foregut consist of cuticle intima, epithelial cells, basal membrane, longitudinal and circular muscles (Fig. 2). The cells on the foregut have no morphological characteristics that are suitable for absorption or secretion [19].

The foregut presents a layer of cubic epithelial cells. Each of epithelium cell has an oval nucleus that is located at the centre of the cell. The lumen of the cell is covered by thick cuticle in order to protect the cell from hard food materials. The cuticle formed as the foregut is originated from folded ectodermal.

Basal membrane covered the outside of epithelial cells and less visible as it is too thin and has one cell thick. The epithelial cells of the crop consists of two complete types of muscles, outer longitudinal muscles and inner circular muscles. However, there are some insect that the circular muscle layer generally being external to the longitudinal layer as stated in reference [20] such as ants [21] - [22] [23] and fruit fly, Anastrepha fraterculus [24]. Nucleus of circular muscle cell is smaller than in longitudinal muscle cell and located at the centre of the cell. In contrast, the nucleus of longitudinal muscle is oval and located at the side of the cell.

The epithelial cells of the crop also show clear folds when that part is empty. These folded surfaces are important as it will increase the surface area when the crop is filled with food. The presence of muscles around it helps in the contraction and expansion of crop.

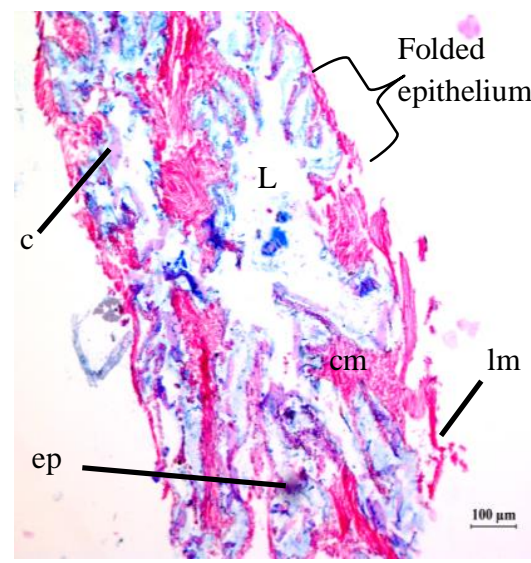

Fig. 2 Tissue section of foregut for the crop (cr) part. c (cuticle); L (lumen); ep (epithelium cell); cm (circular muscle); $1 \mathrm{~m}$ (longitudinal muscle) (10X).

Midgut: The cross section of $P$. serratipes midgut shows that it is lined with one cell thick of columnar epithelial cells that have nucleus at the center of the cell. The cells are covered by basal membrane at the base of the cells (Fig. 3a). This type of cells normally found on the surface of the organ that works for absorption [25].

There are microvilli on the surface of the columnar epithelial cells which secrete a thin membrane that known as perithrophic membrane (Fig. 3a). This membrane was first described by reference [26] on Pieris brassicae. This membrane will surround the food and separate it from the midgut wall thus prevent the epithelial from injuries or damage [27]. Apart from that, perithrophic membrane also permeable to digestive enzyme and digestion product [27]. Regenerative cells were found scattered at the base of epithelial cells. It also called nidi cells (Fig. 3b). The function is to replace the worn out or old epithelial cells [28] $-[29]$.

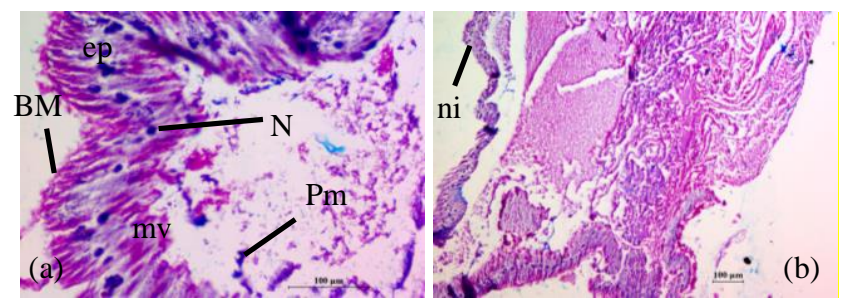

Fig. 3 a) Tissue section of the midgut. L (lumen); ep (epithelium cell); $\mathrm{BM}$ (basal membrane); Pm (perithrophic membrane); $\mathrm{N}$ (nucleus); mv (microvilli) (40X). b) Tissue section of midgut. ni (nidi cells) (10X).

Hindgut: The sequences of the layers of hindgut from the lumen are cuticles intima, epithelial cells, longitudinal muscles and circular muscles respectively (Fig. 4). Hindgut is ectodermal origin similar as the foregut. The lumen of hindgut is smaller due to the more cuticles folded. The folds of the cuticles resulting from the folding of one cell thick cubic epithelial cells. These cubic epithelial cells located along the inner part cuticles intima. This folds forms some spaces for the delivery of water and small molecules between the cells [30]- [31]. 


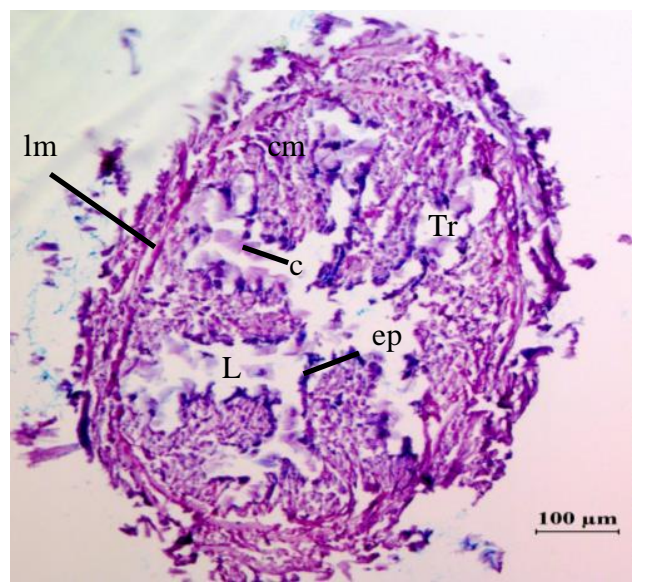

Fig. 4 Tissue section of hindgut. L (lumen); c (cuticle); ep (epithelium cell); $1 \mathrm{~m}$ (longitudinal muscle); $\mathrm{cm}$ (circular muscle; $\mathrm{Tr}$ (trachea) (10X). All the tissues were stained with Alcian blue and PAS reagent.

\section{Serotonin Distribution on Digestive Tract}

Foregut: Immunohistochemical analysis shows that there are distribution of serotonin-like immunoreactive processes reaction along the digestive tract of $P$. serratipes. Serotoninlike immunoreactive processes can be seen in all parts of digestive tract, foregut (Fig. 5a), midgut (Fig. 6a) and hindgut (Fig. 7a). The serotonin distribution are scattered and uneven along the foregut (Fig. 5a). The locality and distribution of serotonin are invisible on the nerve fibers but more to be in a particular spots or specific cells. The tissue cross section of foregut shows that serotonin are distributed on the epithelium folded (Fig. 5b). Other insects that also have serotonin on their foregut are ant, Camponotus mus [32], fruit fly, Drosophila melanogaster [33] - [7], and locust, Locusta migratoria [34]. The absent of serotonin on the nerve fibers proved that the function of serotonin on the foregut are not acts as neurotransmitter but they serves to increase the frequency and amplitude of visceral muscles contractions. This is also supported by the study that had been conducted on locusts, L. migratoria and cockroaches, Leucophaea maderae [35] - [36].

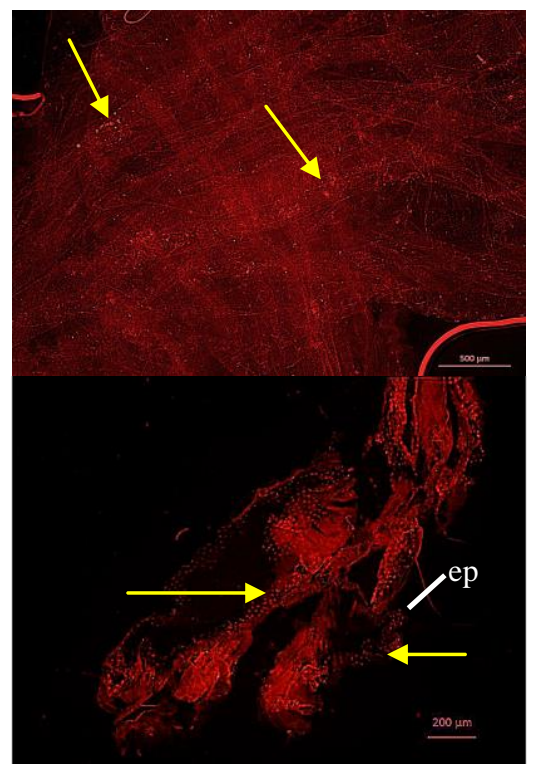

Fig. 5 a) Serotonin distribution on the foregut of P.serratipes (yellow arrows). b) Serotonin on the tissue cross section (yellow arrows) of foregut. ep (epithelium); $\operatorname{lm}$ (longitudinal muscles); $\mathrm{cm}$ (circular muscles).
Midgut: There are more serotonin distribution on the midgut of $P$. serratipes compared to other parts as it is the most important part in the digestion of stick insects. According to reference [16], midgut is important for enzyme secretion, digestion and nutrients absorptions.

The serotonin distribution formed long parallel and fibrous lines on the outer muscles, circular muscles (Fig. $6 a)$. For the tissue cross section, serotonin distribution can be seen clearly on the circular muscles that surrounded the outer part of midgut and on the epithelium folded (Fig. 6b).

This pattern of distribution also can be found in locusts, Locusta migratoria where the serotonin-like immunoreactive processes running in vertical and horizontal parallel lines form a ladder-like network [34].

The serotonin distribution on the muscles suggested that serotonin helps in contractions of muscles and also will aid in the food transportation. As a solid feeder, an efficient muscles control is required in order to ensure that the food can digested properly. It is also supported by the study on Rhodnius prolixus [37]. In $R$. prolixus, the process on the mesothorax ganglion had stimulated the digestive tract [37] $-[38]$.

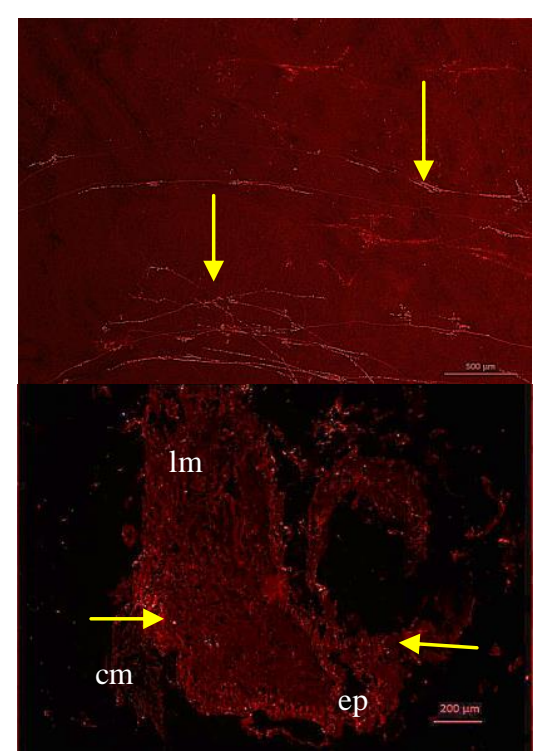

Fig. 6 a) Serotonin distribution on the midgut of P.serratipes (yellow arrows). b) Serotonin on the tissue cross section (yellow arrows) of midgut. ep (epithelium); lm (longitudinal muscles); $\mathrm{cm}$ (circular muscles).

Hindgut: The serotonin-like immunoreactive processes on the hindgut of P.serratipes shows the lowest compared to the other parts (Fig. 7a). For the tissue cross section, serotonin are uneven and scattered on the circular and longitudinal muscles (Fig. 7b). The serotonin distribution on the hindgut also more abundant on the muscles and it also can be concluded that serotonin plays important roles in controlling the expanding and contraction of muscles. 


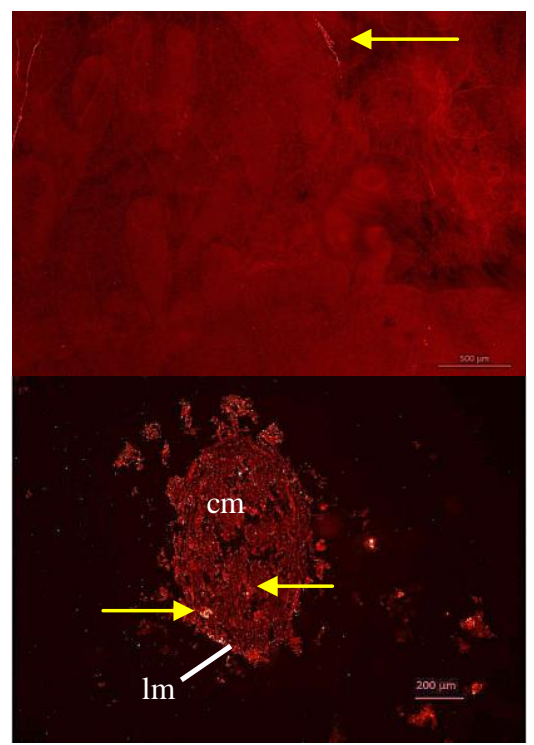

Fig. 7 a) Serotonin distribution on the hindgut of P.serratipes (yellow arrows). b) Serotonin on the tissue cross section (yellow arrows) of hindgut. ep (epithelium); lm (longitudinal muscles); $\mathrm{cm}$ (circular muscles).

There are no serotonin-like immunoreactive processes occur on the foregut (Fig. 8a), midgut (Fig. 8b) and hindgut (Fig. 8c) of controlled slides because without no primary antibody, the secondary antibody unable to bind and react with the antigen.

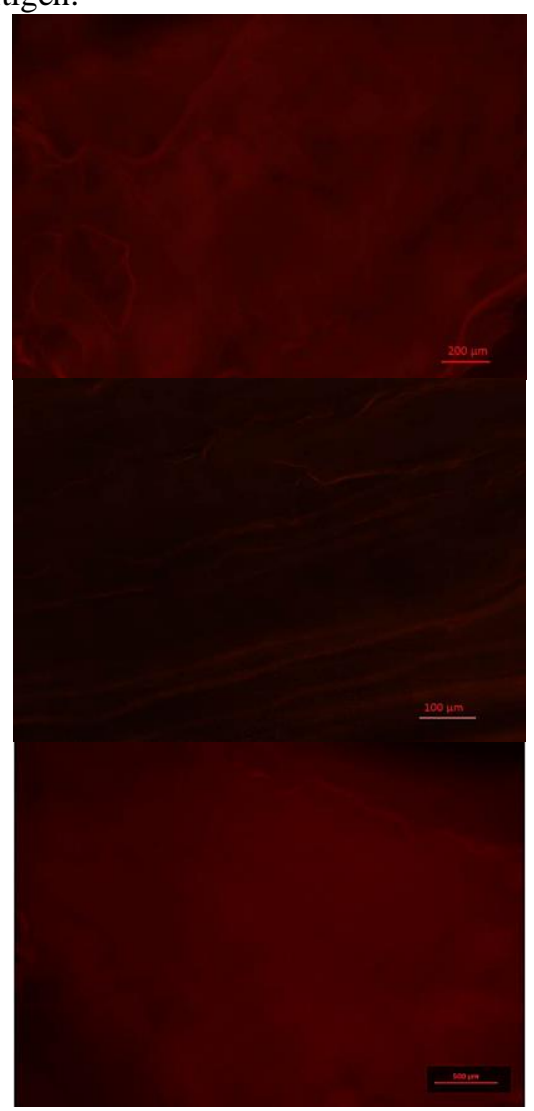

Fig. 8 No serotonin-like immunoreactive process occurred on the digestive tract of controlled slides. a) Foregut. b) Midgut. c) Hindgut.

\section{ACKNOWLEDGMENT}

The authors would like to thanks Universiti Kebangsaan Malaysia for the facilities and grant provided (Young Researcher Encouragement Grant, GGPM - 2013 - 089 \& FRGS/1/2015/WAB13/UM/02/1), Nazca Scientific Sdn.
Bhd. and Olympus from Universiti Putra Malaysia for the fluorescence microscope. We also would like to express our gratitude to Dr. Azman Sulaiman for helping us with the samples.

\section{REFERENCES}

[1] F. Slansky, "Insect nutrition: An adaptationists perspective," Florida Entomol, vol. 65, pp. $45-71,1982$. http://dx.doi.org/10.2307/3494145

[2] R.F. Chapman, The insects structure and function, 4th ed. Cambridge University Press, 1998, pp. 770. http://dx.doi.org/10.1017/CBO9780511818202

[3] C. Cruz-Landim, "Ultra-estrutura e função do tubo digestive dos insetos,". Aciesp, vol. 44, pp. $28-41,1985$.

[4] W.R. Terra, "Physiology and biochemistry of insect digestion. An evolutionary perspective," Brazilian J. Med. Biol. Res, vol. 21, pp $675-734,1988$

[5] G.O. Bedford, "Biology and ecology of the Phasmatodea," Annu. Rev. Entomol, vol. 23, pp. 125 - 149, 1978.

http://dx.doi.org/10.1146/annurev.en.23.010178.001013

[6] Q. Yuan, W.J. Joiner, and A. Sehgal, "A sleep-promoting role for the Drosophila serotonin receptor 1A," Curr Biol, vol.16, pp. 1051 1062, 2006 http://dx.doi.org/10.1016/j.cub.2006.04.032

[7] W.S. Neckameyer, "A trophic role for serotonin in the development of a simple feeding circuit," Dev Neurosci, vol. 32, pp $217-237,2010$. http://dx.doi.org/10.1159/000304888

[8] J.A. Dow, "Insect midgut function," Adv. Ins. Physiol, vol. 19, pp $187-328,1986$ http://dx.doi.org/10.1016/S0065-2806(08)60102-2

[9] S.H.P. Maddrell, and B.O.C. Gardiner, "The permeability of the cuticular lining of the alimentary canal," J. exp. Biol, vol. 85 pp. 227 $-237,1980$.

[10] J.E. Trehernb, "Glucose absorption in the cockroach," J. exp. Biol, vol. 34 , pp. $478-485,1957$.

[11] J.E. Trehernb, "The absorption of glucose from the alimentary canal of the locust, Schistocerca gregaria (Forsk.)," J. exp. Biol, vol. 35, pp. $297-306,1958$.

[12] J.E. Trehernb, "Gut absorption,” A. Rev. Ent, ia, pp. 43 - 58, 1967.

[13] M.T. Cheeseman, and G. Pritchard, "Proventricular trituration in adult carabid beetles (Coleoptera: Carabidae)," J. Insect Physiol, vol. 30, pp. $203-209,1984$. http://dx.doi.org/10.1016/0022-1910(84)90004-0

[14] R.J. Elzinga, and T.L. Hopkins, "Foregut microspines in four families of cockroaches (Blattaria)," Int. J. Insect Morphol. Embryol, vol. 23 pp. $253-260,1994$ http://dx.doi.org/10.1016/0020-7322(94)90022-1

[15] N, Szinwelski, M.S. Rodrigues, M.R. Pereira, J.E. Serrao, and C.F Sperber, "Proventiculus of three Nemobiinae crickets (Orthoptera: Grylloidea: Trigonidiidae)," J. Orthoptera Res, vol. 18, pp. 59, 2009. http://dx.doi.org/10.1665/034.018.0104

[16] J.L. Nation, Insect physiology and biochemistry, 2nd ed. USA: Taylor \& Francis Group, 2008.

[17] V.B. Wigglesworth, Insect Physiology, London: Science Paperback, 1966.

[18] P. Lyonet, “ Trait $\tilde{A} \odot$ anatomique de la chenille qui ronge Ic bois de saule,". pp. 616, 1762.

[19] D.O. Azevedo, M.D.C.Q. Fialho, N.C. Vargas, E.F. Vilela, J.C. Zanuncio, and J.E. Serrão, "Morphology of the digestive tract of Cladomorphus phyllinus (Phasmatodea: Phasmidae)," Florida Entomologist, vol. 96, no. 4, pp. 1417 - 1423, 2013. http://dx.doi.org/10.1653/024.096.0421

[20] V.B. Wigglesworth, The principles of insect physiology, New York: John Wiley, 1974.

[21] F.H. Caetano, "Morfologia comparada do trato digestivo de formigas da subfamília Myrmicinae (Hymenoptera: Formicidae)," Pap. Avulsos Zool., vol. 35, pp. 257 - 305, 1984.

[22] F.H. Caetano, "Anatomia, histologia e histoquímica do sistema digestivo e excretor de operárias de formigas (Hymenoptera, Formicidae)," Naturalia, vol. 13, pp. 129 - 174, 1988.

[23] F.H. Caetano, Endosymbiosis of ants with intestinal and salivary gland bacteria. (In: Insect Endocytobiosis: Morphology, Physiology, Genetic, Evolution Werner Schwemmler editor). Boca Raton: CRC Press, 1989 , pp. $57-75$

[24] F.H. Caetano, V.N. Solferini, F.B. de Britto, D.S. Lins, T. Aluani, V. G. de Brito, and F.J. Zara, "Ultra morphology of the digestive system of Anastrepha fraterculus and Ceratitis capitata (Diptera: 
Tephritidae)," Braz. J. morphol. Sci., vol. 23, no. 3 - 4, pp. 455 462, 2006.

[25] B, Young, and J.W. Heath, Wheather's functional histology a text and colour atlas, 4th ed. London: Harcourt Publishers Limited, 2000.

[26] M. Aubertot, "Les sacsperitrophiques desc larves d' Aeschna (Odonates: Anisopteres), leur evacuation, periodique," C.R. Soc. Biol., vol. 1117, pp. $746-748,1934$.

[27] A.B. Sarwade, G.P. and Bhawane, "Anatomical and histological structure of digestive tract of adult Platynotus belli. F (Coleoptera: Tenebrionidae)," Biological Forum - An International Journal, vol. 5 , no. 2 , pp. $47-55,2013$

[28] O. Cakici, and G. Ergen, "Histologic description of midgut in Melanogryllus desertus (Pallas, 1771) (Orthoptera: Gryllidae)," Biharean Biologist, vol. 6, no. 2, pp. 108 - 111, 2012.

[29] V. Wanderley-teixeira, A.A.C. Teixeira, F.M. Cunha, M.K.C.M. Costa, A.F.S.L. Veiga, J.V. and Oliveira, " Histological description of the midgut and the pyloric valve of Tropidacris collaris (Stoll, 1813) (Orthopetera: Romaleidae)," Braz. J. Biol., vol. 66, no. 4, pp. 1045 $1049,2006$.

http://dx.doi.org/10.1590/S1519-69842006000600011

[30] C. Cruz-Landim, "Ultrastructure of the ileum epithelium of Melipona quadrifasciata anthidiodes (Hymenoptera, Apidae, Meliponinae)," $J$. Morphol., vol. 222, pp. 191 - 201, 1994. http://dx.doi.org/10.1002/jmor.1052220206

[31] C.G. Santos, and J.E. Serrao, "Histology of the ileum in bees (Hymenoptera: Apoidea)," Braz. J. Morphol. Sci., vol. 23, no. 3 - 4, pp. $405-413,2006$.

[32] A. Falibene, W. Rossler, R. Josens, "Serotonin depresses feeding behaviour in ants," J. Insect Physiol., vol. 58, pp. 7-17, 2012. http://dx.doi.org/10.1016/j.jinsphys.2011.08.015

[33] V. Budnik, C.F. Wu, and K. White, "Altered branching of serotonincontaining neurons in Drosophila mutants unable to synthesize serotonin and dopamine,” . J. Neurosci., vol. 9, pp. 2866 - 2877 , 1989.

[34] G. Molaei, and A.B. Lange, "The association of serotonin with the alimentary canal of the African migratory locust, Locusta migratoria: distribution, physiology and pharmacological profile," J. Insect Physiol., vol. 49, pp. 1073 - 1082, 2003. http://dx.doi.org/10.1016/j.jinsphys.2003.08.004

[35] H. Huddart, and A.C. Oldfield, "Spontaneous activity of foregut and hindgut visceral muscle of the locust, Locusta migratoria-II. The effect of biogenic amines," Comparative Biochemistry and Physiology C., vol. 73, pp. 303-311, 1982. http://dx.doi.org/10.1016/0306-4492(82)90126-5

[36] B.J. Cook, and G. Holman, "Comparative pharmacological properties of muscle function in the foregut and the hindgut of the cockroach Leucophaea madrae," Comparative Biochemistry and Physiology C, vol. 61 , pp. $291-295,1978$. http://dx.doi.org/10.1016/0306-4492(78)90057-6

[37] A.B. Lange, I. Orchard, F.M. Barrett, "Changes in hemolymph serotonin levels associated with feeding in the bloodsucking bug, Rhodnius prolixus," J. Insect Physiol., vol. 35, pp. 393 - 400, 1989. http://dx.doi.org/10.1016/0022-1910(89)90113-3

[38] I. Orchard, "Serotonin: a coordinator of feeding-related physiological events in the blood-gorging bug, Rhodnius prolixus," Comp. Biochem. Physiol. A Mol. Integr. Physiol., vol. 144, pp. 316 - 324, 2006.

http://dx.doi.org/10.1016/j.cbpa.2005.11.010 